\title{
Sammanbrott och tillfrisknanden
}

\author{
Kvinnors livsberättelser om psykiska kriser
}

I BÖRJAN AV 2OIO-TALET SKREV den finländska författaren Minna Lindberg i sin självbiografiska bok Diagnos $F_{32 . I}$ (2OI2) om sin önskan att dö, om sina tankar på att ta livet av sig. ${ }^{1}$ Hon hade hamnat i en livskris och beskriver i början av berättelsen hur hon är sömnlös, trött och på tröskeln att ge upp:

Just nu är det en daglig kamp mellan mina inre viljor och oviljor och hittills har jag valt livet. Jag är inte säker på att det varit det rätta valet men för stunden är det i alla fall. Kanske kan någon hjälpa mig att bli av med ångest och allt obehag, bli av med den konstanta smärtan under bröstet som skär varje gång jag andas in, klumpen $\mathrm{i}$ halsen som inte försvinner och det svidande brännande i strupen. ${ }^{2}$

Minna Lindberg valde att med hjälp av skrivandet studera sitt psykiska tillstånd och sin livskris samt att ge ut sin berättelse. Intresset för att studera psykiskt lidande genom att iaktta sina egna erfarenheter

I. F $32_{3}$ är diagnoskod (ICD) för depression. $F_{32 . I}$ hänvisar till den medelsvåra formen av depression. ICD (International Statistical Classification of Diseases and Related Health Problems) upprätthålls av Världshälsoorganisationen WHO och är i bruk också i Finland, https://icd.who.int/browsero/2015/en\#/F 32 (hämtad I5/3 20I9), Depressio. Käypä hoito -suositus. Suomalaisen Lääkäriseuran Duodecimin ja Suomen Psykiatriyhdistys ry:n asettama työryhmä. Helsinki: Suomalainen Lääkäriseura Duodecim 2016, tillgänglig på nätet, http://www.kaypahoito.fi/sv (häm$\operatorname{tad}$ 9/8 20I9), http://www.kaypahoito.fi/web/kh/suositukset/suositus?id=hoi50023 (hämtad I4/6 2org). För tillfället har en fullständig version av rekommendationen för god medicinsk praxis beträffande depression publicerats endast på finska. En patientversion om depression som presenterar innehållet kortfattat finns också på svenska, https://www.kaypahoito.fi/sv/khrooo29 (hämtad I4/6 2019).

2. Minna Lindberg, Diagnos $F_{32 . I}$, Helsingfors: Oy Litorale Ab 2012, s. 9. 
och skriva om dem är inte något helt nytt, men den här typen av livsberättelser utgivna i bokform är en nutida trend. Enligt Thomas Couser upplever sjukdomsberättelser, liksom det jag kallar kvinnors livsberättelser om psykiska kriser, i dag en blomstringsperiod. ${ }^{3}$ Också Ann Hunsaker Hawkins hävdar i sin bok från I990-talet att sjukdomsberättelsen, eller "patografin", är en samtida genre som har vuxit fram under de senaste decennierna. ${ }^{4} \mathrm{På}$ samma sätt hänvisar litteraturvetaren Lisbeth Larsson till den samtida svenska litterära kulturen och skriver att det funnits ett stort intresse för att skriva och ge ut biografiska berättelser under slutet av igoo- och början av 2000-talet; det handlar alltså om alla typer av"sanna historier", inte bara sjukdomsberättelser. ${ }^{5}$ I en amerikansk kontext har Leigh Gilmore och Julie Rak skrivit om memoarboomen,"memoir boom”, den starka framväxten av icke-fiktiv litteratur om personliga livshistorier från 1990-talet framåt. ${ }^{6}$ Det ges ut allt flera olika slags memoarer, vittnesmål och historier om identitetssökande, och både skrivandet och utgivningen av sjukdomsberättelser kan ses som en del av detta större fenomen. ${ }^{7}$ Också den svenska litteraturvetaren Christine Sarrimo är

3. Couser använder termen "autopathography", autobiografiska berättelser om sjukdom eller funktionshinder ("disability"), G. Thomas Couser,"Autopathography: Women, Illness and Life-Writing", Ricia Anne Chansky \& Emily Hipchen (eds.), The Routledge Auto/biography Studies Reader, Milton Park, Abingdon, Oxon: Routledge 2016, s. 95-100.

4. Ann Hunsaker Hawkins, Reconstructing Illness: Studies in Pathography, 2nd ed., West Lafayette: Purdue University Press I999, s. 3-4.

5. Lisbeth Larsson, "De sanna berättelsernas återkomst och förvandlingar", Nordic Women's Literature (online) 20I6, https://nordicwomensliterature.net/se/2016/10/13/ de-sanna-berattelsernas-aaterkomst-och-forvandlingar/(hämtad I4/6 20I9). Se också Sidonie Smith \& Julia Watson, Reading Autobiography, nnd ed., Minneapolis, London: University of Minnesota Press 20I0, s. I26-I27; Alex Zwerdling, The Rise of the Memoir, Oxford: Oxford University Press 2017, s. I, https://doi.org/ro.Io93/ acprof:oso/9780198755784.0o1.ooor.

6. Leigh Gilmore, The Limits of Autobiography: Trauma and Testimony, Ithaca, NY: Cornell University Press 20I8, s. I-2; Julie Rak, Boom!: Manufacturing Memoir for the Popular Market, Waterloo, ON: Wilfrid Laurier University Press 2013, s. 3-I7; Julie Rak, "Are Memoirs Autobiography? A Consideration of Genre and Public Identity", Ricia Anne Chansky \& Emily Hipchen (eds.), The Routledge Auto/biography Studies Reader, Milton Park, Abingdon, Oxon: Routledge 2016, s. 202-208.

7. Se också Tanja Reiffenrath,"Rewriting Cure: Autobiography as Therapy and Discursive Practice", Kerstin Shands et al. (eds.), Writing the Self: Essays on Autobiography and Autofiction, Södertörn: Södertörns högskola 2015, s. 359-36o. Finns även elektroniskt, http://urn:nbn:se:sh:diva-28392 (hämtad I3/8 20I9). 
inne på samma linje och menar att orsaken till de personliga berättelsernas popularitet är den senmoderna "individualiseringsideologin" som hävdar individens roll och framträdande i kulturen, och som också innebär en "intimisering” av det här framträdandet. Med detta menar hon att vi inte bara skapar ett offentligt jag, utan allt oftare skriver om det privata, intima och till och med det sjuka jaget. ${ }^{8}$

I den här artikeln diskuterar jag kvinnors livsberättelser och psykiska kriser. Jag frågar mig hur ett jag som upplever psykisk sjukdom skrivs fram i kvinnors självbiografiska texter. Syftet är också att historiskt kontextualisera detta självbiografiska skrivande. Mitt primärmaterial är tre texter från 20Io-talet, Minna Lindbergs Diagnos $F_{32 . I}$ (2012), Pauliina Vanhatalos Keskivaikea vuosi. Muistiinpanoja masennuksesta (20I6, sv. Mellansvårt år. Anteckningar om depression) och Alexandra Sippus "Önskan att dö, viljan att leva" (20I7). ${ }^{9}$ Alla handlar om depression i nutiden, det senmoderna 2000-talet, där just depressionen har blivit en allmän diagnos för människor som mår dåligt mentalt, för patienter som oftast är just kvinnor. Kvinnors sjukdomsberättelser har vuxit fram starkt men inte studerats särskilt mycket. Thomas Couser skriver att ny forskning visserligen intresserat sig för kvinnors kroppslighet, men att man ändå inte uppmärksammat den växande kategorin av sjukdomsautobiografier, ofta skrivna av kvinnor. ${ }^{10}$ Den här artikeln har alltså en lucka att fylla här.

De texter som jag analyserar kallar jag här"livsberättelser", men de kan också ses som autobiografier eller autobiografiska texter eftersom de berättar en icke-fiktiv livshistoria och sjukdomshistoria i första person. Enligt den välkända definitionen av Philippe Lejeune är autobiografin "en retrospektiv prosaberättelse skriven av en verklig person, om denna persons tillvaro, i vilken fokus ligger på hans personliga liv,

8. Christine Sarrimo, Jagets scen. Självframställning i olika medier, Göteborg: Makadam 20I2, s. 34-36, 63-65, 69 .

9. Lindberg, Diagnos $F_{32 . I}$; Pauliina Vanhatalo, Keskivaikea vuosi. Muistiinpanoja masennuksesta, Helsinki: Kustantamo S\&S 2or6; Alexandra Sippus: "Önskan att dö, viljan att leva. Min egen berättelse", Alexandra Sippus (red.), Överleva eller leva? Att bli frifrån depression, Vasa: Scriptum 20I7, s. IO5-I2I. Förutom Sippus text innehåller boken fyra andra erfarenhetsberättelser och fyra texter av yrkesmänniskor inom psykiatrisk vård.

ı. Couser, "Autopathography: Women, Illness and Life-Writing", s. 95. 
särskilt på berättelsen om hans personlighet”. ${ }^{11}$ Den här definitionen uppfylls i Lindbergs, Vanhatalos och Sippus texter."Livsberättelse” är ändå ett fungerande begrepp eftersom jag kontextualiserar sjukdomshistorierna tidsmässigt och historiskt. Möjligheterna eller modellerna för att framställa sitt jag, sin livskris eller sin inre kamp har inte alltid varit likadana och den senmoderna modellen för sjävbiografin eller "autobiografin" har inte varit gällande i äldre tid. Som kulturhistoriker intresserad av livsberättelser och hälsans historia utgår jag från nuet men ser det som viktigt att ta hänsyn till historiska förändringar och sätta fenomen vi möter i dag i ett historiskt sammanhang. Därför ger jag också en översikt om kvinnors livsberättelser och hur mentala störningar, livskriser och själslig kamp uppfattats och definierats under tidigare tidsperioder.

Till texterna hänvisar jag med termerna "självbiografi", "livsberättelse" och "sjukdomsberättelse". Syftet är inte att entydigt genrebestämma texterna, eller diskutera relationerna mellan olika genrebeteckningar. Jag tar snarare fasta på det som är gemensamt för många olika typer av livsberättelser, för att undersöka berättelserna som identitetsskapande praktiker, bekännelser och vittnesmål, samt studera jagets framställning i text.Jag använder termen "jaget" och "det sjuka/depressiva jaget" för att analysera hur identitet skapas i text.

Inspiration till frågan hur det sjuka jaget, en depressiv eller mentalt sjuk identitet skapas, har jag hämtat från litteraturvetaren Jens Brockmeier som introducerat begreppet"autobiografisk process". Brockmeier skriver att autobiografin inte är något vi tar fram ur minnet, som ur ett arkiv, utan att skrivandet av en autobiografi är en hermeneutisk process i vilken vi ger oss själva mening och använder resurser från många olika kulturella världar. När kvinnorna i min studie skriver om sina psykiska kriser försöker de alltså ge mening åt sina erfarenheter, känslor och tankar. Den här processen är narrativ och dynamisk, vilket betyder att man blandar lingvistiska, affektiva och kognitiva element. Kärnan i detta tänkesätt är att jaget kommer till genom att

II. "Retrospective prose narrative written by a real person concerning his own existence, where the focus is his individual life, in particular the story of his personality", Philippe Lejeune,"The Autobiographical Pact", Anne Chansky \& Emily Hipchen (eds.), The Routledge Auto/biography Studies Reader, Milton Park, Abingdon, Oxon: Routledge 20I6, s 34-48, citatet på s. 34. Översättning till svenska: KT. 
det berättas. ${ }^{12}$ I mitt material sker berättandet genom skrivandet och målet för den som skriver är alltså att kombinera jaget och sjukdomen samt ge det hela mening.

I artikeln analyserar jag texter som beskriver kvinnornas erfarenhet och som är utgivna i bokform. De har ett annat kommunikativt syfte än privata texter men delvis fungerar de på precis samma sätt. ${ }^{13}$ Man berättar om sitt liv genom att beskriva händelser och erfarenheter och samtidigt konstruerar man ett jag som är den som känner och lider och som är subjektet för sina egna erfarenheter, oberoende av om syftet är att publicera texten eller inte. Från det här perspektivet kan skrivandet ses som en terapeutisk praktik; "skrivandet gör det möjligt för patienter att bygga upp en berättelse som ger (nya) betydelser åt deras erfarenheter", skriver autobiografiforskaren Tanja Reiffenrath. ${ }^{14}$

Erfarenheterna och symptomen som förknippas med sjukdomen, som i mitt primärmaterial är depression, har lett till en diagnos och det innebär att det vetenskapliga språket i berättelserna blandas med det vardagliga. Med diagnosen följer att individens lidande definieras enligt en standardlista av symptom, vilket enligt psykologen Michelle Lafrance betyder att"den subjektiva erfarenheten av lidande blir sedd som ett objektivt tecken på patologi” ${ }^{15}$ Den här dialogen med den psykiatriska vetenskapen påverkar den subjektiva erfarenheten. Men den är också bunden till sin historiska kontext. Som historikern Joan W. Scott skriver, föds erfarenheten i interaktion med den diskursiva världen. ${ }^{16}$ Den världen förändras över tid.

I2. Jens Brockmeier, Beyond the Archive: Memory, Narrative and the Autobiographical Process, Oxford: Oxford University Press 2015, s. 14, https://doi.org/ro.Io93/ acprof:oso/9780199861569.001.00or.

I3. Sarrimo, Jagets scen, s. 20.

I4. "writing allows patients to craft a narrative that attributes (new) meanings to their experiences", Reiffenrath, "Rewriting Cure", s. 359-368, citat på sidan 360. Översättning till svenska: KT.

I5. "subjective experiences of suffering become viewed as objective signs of pathology", Michelle N. Lafrance, Women and Depression: Recovery and Resistance, London \& New York: Routledge 2009, s. 2-3, https://doi.org/IO.4324/9780203889718. Översättning till svenska: KT.

I6. Joan W. Scott, "Experience", Sidonie Smith \& Julia Watson (eds.), Women, Autobiography, Theory: A Reader, Madison, Wisconsin: The University of Wisconsin Press, s. 57-71. 
Sociologen Arthur Frank uttrycker diskursens och interaktionens betydelse så här: "sjuka människor skapar för familj och vänner en berättelse, en ny version av vad doktorn har sagt".${ }^{17}$ De berättar alltså inte bara om sina ursprungliga smärtor och symptom utan tar in medicinska termer och läkarnas utsagor i sina egna berättelser. I det moderna medicinska mötet har den medicinska berättelsen mer makt och därför kallar Arthur Frank patienten för den "narrativt underlägsna", "narrative surrender". Han menar att patienter kanske allt mera ger upp sin egen röst och upprepar medicinens framställningar av deras tillstånd. ${ }^{18}$ Trots att patientens perspektiv är viktigt att diskutera, menar jag att dennas röst inte utgår från ett helt fritt val. Min utgångspunkt är socialkonstruktivistisk och jag tror inte på någon helt autentisk erfarenhet utanför språket och kulturen. Patienten lånar termer inte bara från det medicinska språket, utan också från till exempel populärkulturen. Samtidigt uppskattar jag de kommunikativa handlingar som människor väljer att utföra för att skapa dialog. Människor vill bli hörda, mötta och förstådda och i det nutida samhället har den här viljan förstärkts.

\section{DET DEPRESSIVA JAGET PÅ INTIMITETENS \\ OFFENTLIGA SCEN}

I 2000-talets nordiska kontext har Ann Heberleins bok Jag vill inte dö, jag vill bara inte leva (2008) lästs av många, och gett upphov till livlig diskussion kring sjukdomsberättelsen roll i kulturen. Särskilt i Sverige var utgivningen av boken, även via dess många paratexter, en stor mediehändelse. ${ }^{19}$ Texten är välkänd, den har satts upp på Dramaten i Stockholm, översatts till flera språk och varit mycket inflytelserik. Man har kallat den en bok som är mer än en bok: "det är ett stycke delat liv, delat lidande ${ }^{20}$ En 3I-årig finsk patient vars berättelse ingår i den

I7. "[i]11 people tell family and friends versions of what the doctor said [...]", Arthur Frank, The Wounded Storyteller: Body, Illness, and Ethics, Chicago [Ill.]: University of Chicago Press 1997, s. 5, https://doi.org/ro.7208\%2Fchicago\%2 F9780226067360.oor.ooor. Översättning till svenska: KT.

I8. Ibid.

19. Sarrimo, Jagets scen, s. 63-88.

20. Åsa Moberg, "Läs recensionen av Ann Heberleins 'Jag vill inte dö, jag vill bara inte leva", Expressen 9/I 2009, https://www.expressen.se/kultur/bocker/las- 
bok som Alexandra Sippus har redigerat (Överleva eller leva? Att bli fri från depression) har kanske läst Heberleins bok för hon skriver om sin depression att" [d] et var den klassiska känslan hos en deprimerad: jag ville inte dö, men jag orkade inte leva”. ${ }^{21}$ Möjligen hänvisar hon till Hamlets klassiska fråga, men också till Heberleins sätt att formulera den ambivalenta dödslängtan hos deprimerade människor.

Enligt Christine Sarrimo är Heberleins bok ett exempel på jaget på scen. Genom att skriva och publicera sin självbiografi som psykiskt sjuk träder Heberlein in i offentligheten, som enligt Sarrimo är en "intimitetens offentlighet", där "ett affektivt medborgarskap konstitueras". ${ }^{22}$ Idén hänger ihop med Leigh Gilmores och Julie Raks diskussion kring att memoarer om det privata livet har blivit populära. Ändå bygger Sarrimo till största delen på amerikanska Lauren Berlant som utforskat intimitet i olika kulturella offentligheter och som menar att privatlivet fătt en ökad status och kommit att ses som det verkliga livet - i motsats till (och på bekostnad av) det kollektiva, politiska livet. Känslor kopplas till verklighet, och till slut sanning. Vid sidan av positiva känslor har också obehagliga och svåra känslor börjat spela en viktig roll i autobiografiska berättelser. Identiteter som vi förväntas uttrycka kopplas ofta "till sexualitet eller till andra av tradition privatlivsanknutna erfarenheter, exempelvis sjukdom", skriver Sarrimo med hänvisning till Berlants synsätt. ${ }^{23}$ Att svåra erfarenheter och känslor samt sjukdomar erbjuds utrymme i den nutida kulturen, i dess intima offentlighet, förklarar sjukdomsberättelsernas framväxt och innebär också att det psykiskt sjuka jaget har framträtt på scenen.

I Finland har bland annat Päivi Storgårds berättelse Keinulaudalla (2013, sv. På gungbrädan) getts ut i den nya affektiva, intima offentligheten på 2000-talet. Diagnosen, som protagonisten Outi får ganska

recensionen-av-ann-heberleins-jag-vill-inte-do-jag-vill-bara-inte-leva/ (hämtad I4/6 2019). Se även Sarrimo, Jagets scen, s. 86.

2I. "Främlingen i spegeln: Emelie, 3 I år", Alexandra Sippus (red.), Överleva eller leva? Att bli fri från depression, Vasa: Scriptum 20I7, s. 42.

22. Sarrimo, Jagets scen, s. 77 .

23. Ibid., s. 78. Lauren Berlant, "Intimacy: A Special Issue", ed. Lauren Berlant, Intimacy, Chicago \& London: The University of Chicago Press 2000, s. I-8. 
sent i berättelsen, är precis som i Heberleins bok bipolär sjukdom. ${ }^{24}$ Denna sjukdom beskrivs som ett tillstånd som "ibland orsakade den typ av fart som tvingade dig att resa". "Nu är farten slut, hjärnan orkade inte längre" säger läkaren när han beskriver insjuknandet. ${ }^{25}$ Växlingarna mellan fart och uppstannande jämförs med gungan i barndomen - då var det viktigt att vara "hurja", våghalsig. ${ }^{26}$ Mot slutet av berättelsen är patienten på ett tryggt ställe och har överlevt. Hoppet och överlevnaden, resan genom helvetet, och att till slut få den rätta diagnosen och balans i livet kan tolkas som bokens centrala tema. Vi kan alla insjukna, lida men också tillfriskna, tycks den säga. Och ingen behöver skämmas. I sjukdomens och sjukhusens intima miljö skapas en individuell depressiv identitet. Identiteten är sårad men med medicinens - och familjens - hjälp har det nya bipolära jaget hittat ett sätt att leva vidare och känna lycka.

Om vi ser på de här sjukdomsberättelserna om bipolaritet utifrån Arthur Franks tankeramar, så kan både Heberlein och Storgård ses som berättare "som söker att återkräva sin egen erfarenhet av lidandet". ${ }^{27}$ Med detta menar Frank att man berättar om sin sjukdom för att ge röst åt en erfarenhet som medicinen inte kan beskriva. Den här synpunkten kan kritiseras för att placera patienten i offrets position, men trots detta är den viktig i den nutida, teknologiskt orienterade biomedicinska kulturen där patienten inte hörs eller blir tillräckligt synlig, i en värld där den medicinska makten och apparaten styr. Trots att han menar att patienter återkräver sin egen erfarenhet, så medger också Frank att patientens berättelser lånar mycket från det professionella psykiatriska språket. Också min tolkning är att den individuella erfarenheten föds i samverkan med den diskursiva världen och upprepar ord från medicinska möten. Också sättet på vilket

24. Om bipolär sjukdom, se till exempel Petteri Pietikäinen, Madness. A History, London, New York: Routledge 2015, s. 20I; David Healy, Mania. A Short History of Bipolar Disorder, Baltimore: The Johns Hopkins University Press 2008, s. 43, I42-I5I.

25. "Se [bipolär sjukdom, kaksisuuntainen mielialahäiriö] aiheuttaa toisinaan juuri sellaista vauhtia, joka pakotti sinut matkalle. Nyt vauhti on loppunut, aivot eivät jaksaneet enää, lääkäri sanoi”, Storgård, Keinulaudalla, s. 233. Översättning till svenska: KT.

26. Ibid.

27. "[...] the storyteller seeks to reclaim her own experience of suffering.", Frank, The Wounded Storyteller, s. I8. Översättning till svenska: KT. 
berättelsen struktureras har kulturella förebilder. Det som Frank kallar "the restitution narrative", tillfrisknandets berättelse, dominerar i kulturen och även människor med cancerdiagnos stöder sig ofta på den. I kamratgrupper avslutar man ofta träffar med att säga att "jag har det bra" ${ }^{28}$ Enligt Frank dominerar den här typen av narrativ i dagens berättelser. Man önskar att den sjuka ska bli frisk igen och denna önskan delas av både de som skriver och de som läser. ${ }^{29}$ Tillfrisknandets narrativ lockar oss alla.

\section{DET DEPRESSIVA JAGET SOM MEDBORGARE I TVÅ LÄNDER}

År 2016 utkom Pauliina Vanhatalos bok Keskivaikea vuosi. Muistiinpanoja masennuksesta. Den handlar inte om bipolär sjukdom utan om depression, om ett år med vinterdepression. Vanhatalo identifierar sig som en introvert person som upplever allt ytterst kraftigt och behöver mera tid att vara ensam än många andra. Hon arbetar hårt och ställer höga krav på sig själv som författare och mor. Hon blir arg, irriterad och trött men hennes självkännedom ökar samtidigt, hennes syn på sjukdomen förändras och på sätt och vis accepterar hon slutligen att depressionen som kommer och går är hennes lott. "Slutligen ger jag upp [...] Jag accepterar att leva mitt tvådelade liv, i dess kontrovers. Jag är medborgare i bägge länder." ${ }^{30}$

Metaforen det dubbla medborgarskapet har sitt ursprung hos den amerikanska författaren Susan Sontag, som i sin essäbok Sjukdom som metafor (I98I, Illness as Metaphor I977) skriver att"[s]jukdomen är livets nattsida, ett mer betungande medborgarskap. Var och en som är född till världen har ett dubbelt medborgarskap, ett i de friskas kungarike och ett i de sjukas". ${ }^{31}$ Susan Sontag skrev egentligen om

28. Ibid., s. 77-79. "I'm fine”. Översättning till svenska: KT.

29. Ibid.

30. "Lopulta annan periksi, en takerru hyviinkään tunteisiin. Suostun kahdeksi jakautuneeseen elämääni, sen ristiriitaan. Olen kansalainen kummassakin maassa”, Vanhatalo, Keskivaikea masennus, s. 229. Översättning till svenska KT.

3I. Susan Sontag, Sjukdom som metafor, översättning av Britt Arenander, Uppsala: Almqvist \& Wiksell I98I, s. 5. "Illness is the night-side of life, a more onerous citizenship. Everyone who is born holds dual citizenship, in the kingdom of the well and in the kingdom of the sick.", Susan Sontag, Illness as Metaphor, New York: Vintage Books I979, s. 3. 
tubekulos och cancer men hänvisade också till sinnessjukdom. Hon argumenterade emot det metaforiska språket och tyckte varken om att romantisera eller demonisera sjukdomar. Enligt Sontag blomstrar ändå bruket av metaforer. Till exempel resan som den insjuknade gör till sjukdomens kungarike, eller hennes besök i gränslandet nära döden, är en viktig metafor i I8oo-talets sentimentala språk. De här sentimentala sjukdomsbeskrivningarna med ursprung i diskursen kring tuberkulos började också förekomma i diskussioner om sinnessjukdom och melankoli, menar Sontag. För att vara en individ blev det under romantiken viktigt och nödvändigt att vara "intressant". Man blev det genom att vara klen, blek och nära döden eller lidelsefull och utanför sig själv på något annat sätt. ${ }^{32}$ Julie Rak är en av de autobiografiforskare som binder det jag som skrivs fram i autobiografin till romantikens idé om den unika personligheten, det romantiska subjektet som föds i skrivandet. ${ }^{33}$ Man kan hävda att den nutida individuella kulturen bygger på den traditionen.

Kravet på att vara intressant och individuell lever kvar i alla autobiografiska praktiker, också i sjukdomsberättelser. I den nutida "individualiseringsideologin" är det starkare är någonsin. ${ }^{34}$ Detta krav ställs i dag på oss alla - vi måste hitta ett individuellt sätt att leva, en identitet som är speciell - på gott och ont. Kravet kan förorsaka stress, men genom att hitta en ny eller förlorad identitet kan man också börja må bättre, menar Lars-Christer Hydén och Jens Brockmeier. Att identiteten förändras är enligt dem någonting som i allmänhet är speciellt viktigt för en berättelse. De skriver så här om intriger där personens identitet förändras:

Att vara sjuk är början på en resa mot nya erfarenheter och en ny identitet. Som vittnen till sin egen förändring tror berättarna i sökandets narrativ att de har lärt sig något värdefullt som de kan ta med sig hem och ge vidare till andra, speciellt till andra lidande. ${ }^{35}$

32. Sontag, Sjukdom som metafor., s. 43-54.

33. Julie Rak,"Are Memoirs Autobiography?", s. 203.

34. Sarrimo, Jagets scen, s. 34-4I.

35. "being ill initiates a journey toward new experience and a new identity. As witnesses to their own transformation, narrators of quest stories believe they have learned something valuable that they can bring home and pass along to others, particularly to other sufferers", Lars-Christer Hydén \& Jens Brockmeier, "Introduction. From 
Enligt min tolkning har Pauliina Vanhatalo skrivit en berättelse i vilken hon har förändrats. Hon har lärt sig vem hon är och godkänt sin nya identitet som en människa med en mörk sida, en medborgare i två länder. Hon har en ny identitet som en person med vinterdepression - inte en människa som har vunnit över sin fiende utan en som har valt att leva med den. Allt detta ses som något viktigt och hon vill dela sin historia, sin autobiografiska process med andra, vilket hon gör genom att ge ut sin berättelse i bokform.

År 2012 utgavs Minna Lindbergs ganska korta berättelse om depression. Hennes Diagnos $F_{32 . I}$ hänvisar till depressionsdiagnosen i den finska medicinska sjukdomstabellen ICDı。 där F 2 2.I. är den kod som läkarna använder när de till exempel sjukskriver någon på grund av depression. ${ }^{36}$ Boken har två delar, "I Ångestens klor" och "Vägen tillbaka till livet", och liksom i många andras berättelser om att ha depression är den psykiska smärtan så stor att den tar skribenten till "helvetet", till det yttersta där hon önskar att hon inte längre fanns, att hon vore död. I Lindbergs fall är berättaren ändå så van vid att analysera sina egna känslor att hon vet att tankar kring att ta sitt liv, en önskan att få cancer eller att bli under en buss och dö, är tecken på att hon är allvarligt sjuk och behöver hjälp. Och hon söker också hjälp innan hon försöker ta sitt liv. ${ }^{37}$

Liksom Vanhatalo funderar också Lindberg mycket på vad depression innebär. Hon reflekterar kring detta och skriver:

'Jaha', tänker jag. Nu är jag sjukskriven för att jag är galen. Eller åtminstone på väg att bli det. Och sjukskriven på grund av att jag inte har hittat livets mening. Jag tycker egentligen det låter så löjligt att jag skämtar om det med de vänner jag berättar det för. ${ }^{38}$

I berättelsen föreslår läkaren sjukskrivning på grund av depression och diagnosen har en viktig roll i berättelsens förlopp. Ett kapitel heter

the Retold to the Performed Story", Lars-Christer Hydén \& Jens Brockmeier (eds.), Health, Illness and Culture. Broken Narratives, New York, London: Routledge 2010 s. 5, https://doi.org/Io.4324/9780203894309. Översättning till svenska: KT.

36. Depressio, Käypä hoito-suositus 2016.

37. Lindberg, Diagnos $F_{32.1}$, s. 52-53.

38. Ibid., s. 55-56. 
"FPA-helvetet" och handlar om avslaget hon får av Folkpensionsanstalten (FPA) på en ansökan om sjukdagpenning. ${ }^{39}$ I det här skedet skämtar Lindberg inte längre om sin depression utan känner sig sjuk, men samtidigt förnekar samhället hennes sjukdom genom avslaget.

Lindberg reflekterar kring sin identitet och medger att sjukdomen på något konstigt sätt sitter i jaget. Den har ett namn i läkarnas och medicinens värld, men diagnosen motsvarar inte alltid känslan. Lindberg skäms över sitt beteende och skriver: "innerst inne förebrår jag mig själv för att jag behandlar de människor som bryr sig om mig så illa. Kanske hela depressionen handlar om att jag straffar mig själv för att jag är som jag är?" ${ }^{40}$ Ur patientperspektiv överväger Lindberg sitt tillstånd, om det handlar om "otillräcklighet" eller om ett medicinskt tillstånd som motsvarar diagnosen $\mathrm{F}_{32 \text {.I }}$ i det psykiatriska klassificeringssystemet. Just så här fungerar den autobiografiska prosessen som Jens Brockmeier diskuterar. I skrivandet möts känslor, kulturella värderingar och lingvistiska val. Kognitiva, affektiva och lingvistiska aspekter separeras ofta men när vi betraktar den autobiografiska processen som en narrativ praktik där vi ger våra liv och våra erfarenheter mening, måste vi förena dem. ${ }^{41} \mathrm{I}$ patienters sjukdomsberättelser förenas många av våra kulturella betydelser och värderingar samt narrativa modeller med de kroppsliga symtom och känslor som patienten har och försöker ge mening.

Lindberg berättar att vägen tillbaka till livet börjar med en bra terapeut. Hon funderar mycket på hur man väljer en terapeut, försöker gå i terapi hos några och konstaterar att alla är olika."Den första är en fri själ medan den andra påminner om min mamma", skriver hon. ${ }^{42}$ Men när hon bestämmer att hon nu påbörjar terapin, och att "oberoende vilkendera jag väljer, kommer det att bli bra", så börjar hon må bättre."Jag vet att nu har jag redan tagit första stegen tillbaka till livet", skriver hon om terapins betydelse. ${ }^{43}$

Lindbergs autobiografiska process och identiteten som föds i texten påminner om hur Vanhatalo accepterar en identitet som en människa

39. Ibid., s. $5^{8}$.

40. Ibid., s. 57 .

4I. Brockmeier, Beyond the Archive, s. I4.

42. Lindberg, Diagnos $F_{32 . I}$, s. 67.

43. Ibid. 
med depression. Också Lindbergs resa till sjukdomens kungarike har varit smärtsam och hon har kommit tillbaka med hjälp av en bra terapeut och älskade medmänniskor. Men fri från depression är hon inte. "Jag vill också visa att man kan leva ett 'helt normalt liv' med depression", skriver hon. ${ }^{44}$ Hon har skrivit fram en ny identitet som hon kan leva med och hon har lärt sig mycket. Utan hjälp av vetenskapen i form av mediciner och terapi klarar hon sig inte och hon behöver i synnerhet stöd av dem som bryr sig om henne. Det som hon också har lärt sig är att hon kan vara elak mot sig själv och att självföraktet finns kvar."Jag lär mig acceptera mina skuggor, mitt mörker och min ångest ", skriver hon. ${ }^{45}$

Både Vanhatalo och Lindberg använder metaforer som sjukdomens kungarike och helvete. De konstruerar ett narrativ för att studera och skriva om sina sjuka och depressiva tillstånd. Det viktiga som de har lärt sig är att man på sätt och vis kan vara frisk i sin sjukdom eller lära sig leva i bägge kungarikena, både i de friskas och de sjukas. Tanja Reiffenrath skriver om den här typen av mellanrumstillvaro, ("in-between-existence") med hänvisning till Arthur Franks term "remission society". Mellanrumstillvaron innebär att många patienter i dagens samhälle som lider av cancer, diabetes, hjärtsjukdomar eller allergier aldrig blir helt friska, men genom sjukdomsberättelser skriver de fram en ny identitet som gör det möjligt för dem att må bättre. Frank och Reiffenrath tycker att vi därför borde ge upp dikotomin frisk-sjuk och i stället ta hänsyn till de här erfarenheterna av mellanrum, erfarenheter av att vara mer eller mindre frisk i sin sjukdom. ${ }^{46}$

\section{DEPRESSIONEN OCH TILLFRISKNANDET}

En syn på sjukdom som påminner om Susan Sontags önskan att lämna det sentimentala och flirten med döden bakom sig erbjuder Alexandra Sippus berättelse "Önskan att dö, viljan att leva”, i boken som hon själv också har redigerat och gett titeln Överleva eller leva? Att

44. Ibid., s. 75 .

45. Ibid., s. 74 .

46. Reiffenrath,"Rewriting Cure", s.36I-362; Frank, The Wounded Storyteller, s. 156-I57. 
bli fri från depression (20I7). Redan titeln hänvisar till tillfrisknandet, möjligheten att lämna sjukdomen bakom sig.

Alexandra Sippus berättelse om depression bygger på hopp och visar vägen mot tillfrisknande. Liksom många före henne beskriver Sippus depressionen inifrån, hur den känns, och hon berättar också sin egen historia: hur sjukdomen bröt ut, utvecklades och kulminerade i ett självmordsförsök. Hon betonar ändå starkt tillfrisknandet och hoppet, ett perspektiv på depression som utifrån Michelle Lafrance är ovanligt. Enligt Lafrance har forskarna" $i$ stort sett ignorerat erfarenheten av att bli frisk från depression" ${ }^{47}$ Detta beror på den nutida medicinska vetenskapens fokus på depression som en sjukdom som aktivt invaderar våra liv och våra kroppar. I motsats till sjukdomen ses hälsan som ett passivt tillstånd som automatiskt återvänder när den aktiva sjukdomen försvinner. Hälsan ses som normal och passiv, och blir därför också osynlig. ${ }^{48}$ En annan orsak till att man inte har fokuserat så mycket på tillfrisknandet är att forskarna först helt nyligen insett att majoriteten av dem som drabbas av depression faktiskt tillfrisknar eller blir bättre. Epidemiologin tyder på att tillfrisknandet borde studeras närmare. ${ }^{49}$

Sippus, som fokuserar på hoppet, vill själv vara ett exempel på en människa som blivit allvarligt sjuk, lidit av depression länge men ändå tillfrisknat helt. Hon skriver:

Idag har jag lärt mig att leva utan depression [...] Det var många år av sjukdom. Många år av mörker, gråt och ångest. Vägen tillbaka till ett friskt liv var lång och tung [...] Jag är inte misslyckad och värdelös. Jag är inte i vägen var jag än är.Jag är inte konstig och annorlunda.Jag är mig själv, den person som jag själv skapat och mår bra av att vara. ${ }^{50}$

Sippus berättelse är ganska kort och vändpunkten kommer då hon får den rätta diagnosen. Diagnosen innebär lättnad och klarhet.

47. Lafrance, Women and Depression, s.3."researchers have largely ignored the experience of recovery from depression". Översättning till svenska: KT.

48. Ibid., s. 3-5.

49. Ibid.

50. Sippus, "Önskan att dö", s. I2O-I2I. 
Jag minns att han [läkaren] först pratade med både mig och mamma och sedan med mig ensam. Det var då jag för första gången fick höra de tre ord som skulle ge mig mycket förståelse både för mig själv och från andra:

"Du är deprimerad."

När jag hörde de orden kändes det som att en sten föll från mitt hjärta. Det var en oerhörd lättnad och jag förstod så mycket mer. Det var inte mig som person det var fel på, jag var sjuk. Det var därför jag inte mådde bra. Att få den förklaringen och diagnosen gjorde mig glad. ${ }^{51}$

Glädjen varar inte länge. Enligt berättelsen märkte Alexandra snart att hon trots diagnosen och medicinen inte mådde bättre. Mörkret kom tillbaka och hon hade självmordsplaner. Dessa planer beskrivs som det enda hon känner och har kontroll över, allt annat är förlorat; hon beskriver sig själv som vilsen, misslyckad, värdelös, handlingsförlamad. Symptomen som skildras är typiska för vår tids depression både då vi ser till den medicinska och den hälsosociologiska diskursen. Den franska sociologen Alain Ehrenberg beskriver depressionen som "en kronisk identitetspatologi" som drabbar"en otillräcklig individ" av vår tid. ${ }^{52}$ Men för Alexandra Sippus är det inte fråga om identitet, om hennes jag eller person, utan om en sjukdom. Resan till sjukdomens kungarike är smärtsam och lång men hon fortsätter, till skillnad från Vanhatalo och Lindberg, inte leva som en medborgare i bägge länder utan väljer att leva bara i det andra riket, hälsans rike. För henne är det möjligt genom att hon betraktar depressionen enbart som ett klart vetenskapligt faktum, något som hon inte ifrågasätter. En sådan definition, valet att se depressionen som ett entydigt medicinskt faktum, innebär att sjukdomen också kan ses som "djävulen" och en fiende - något som man måste försöka bli fri från. Sippus skriver att hon efter det andra terapiåret började må bättre och att:"[J]ag höll på att komma loss ur depressionens grepp." ${ }^{53}$ Enligt min tolkning väljer

5I. Ibid., s. III.

52. Alain Ehrenberg, The Weariness of the Self: Diagnosing the History of Depression in the Contemporary Age, Montreal, Ithaca: McGill-Queen's University Press 2oro, s. I63-I64." The inadequate individual"; "a chronic identity pathology". Översättning till svenska: KT.

53. Sippus, "Önskan att dö”, s. II8. 
Sippus att i berättelsen ge sin protagonist en roll av en som kämpar och som vinner till slut. Hon hämtar definitionen av sin fiende från det medicinska språket och med hjälp av denna syn, där sjukdomen inte sitter i jaget - eller inte får fotfäste i identiteten - blir det möjligt att skriva en berättelse i vilken man blir fri från sjukdomen. Detta bär i sig på ett viktigt etiskt budskap: att det i allt lidande finns hopp och att det är möjligt att bli helt frisk.

I det följande kommer jag att sätta de tre berättelser som jag hittills analyserat $i$ en historisk kontext. Dels diskuterar jag depressionens långa historia, dels den långa historien av kvinnors personliga (självbiografiska) skrivande. Till slut sammanfattar jag min tolkning av kvinnors depressionsberättelser på 2000-talet i relation till sammanbrott och tillfrisknande, samt till berättelsernas syn på vad det betyder att vara psykiskt frisk eller sjuk.

\section{TidsLinjer}

Att man har det svårt, att man känner sig nedstämd och vilsen är inte bara ett nutidsfenomen. I depressionens och melankolins idéhistoria kan man gå ända tillbaka till den lärda, berömda engelsmannen Robert Burton. Han skrev sitt massiva opus The Anatomy of Melancholy (162I), för att på djupet studera de sinnestillstånd och den själsliga smärta han själv led av - melankoli. Melankolins historia är värd att kort diskutera, då melankolin är en föregångare till diagnoser som depression och bipolaritet även om ingen rak linje kan dras från melankoli till dagens tillstånd av nedstämdhet. ${ }^{54}$

Burton skrev drygt tusen sidor om nästan alla aspekter av melankoli, dess vardagliga former som förde med sig sorg och nöd, motstånd och kriser men också de "passioner" som ledde till "stark skräck och stark förtvivlan", de två huvudsakliga symptomen på melankoli. ${ }^{55}$

54. Jennifer Radden, Moody Minds Distempered. Essays on Melancholy and Depression, Oxford: Oxford University Press 2009, s. 6-io, 97-98.

55. Karin Johannisson, Melankoliska rum. Om ångest, leda och sårbarhet i förfluten tid och nutid, Stockholm: Albert Bonniers Förlag 2009, s.32-34. Citatet enligt Johannisson. Se också Robert Burton, The Anatomy of Melancholy: What It Is, with All the Kinds, Causes, Symptoms, Prognostickes E Several Cures of It, ed. Holbrook Jackson, New York: Vintage Books 1977, särskilt s. 259-262 i den första delen (The First Partition). 
Burtons melankoli var en blandning av konkreta fysiska symptom och de bekymmer som hängde ihop med ett kontemplativt, tänkande sinne. På hans tid fick melankolin en speciell aura av genialitet och blev en kulturell merit för lärda, intelligenta personer. Paradoxalt nog existerade den samtidigt som en kroppslig sjukdom utan denna glamorösa dimension. Historikern Erin Sullivan skriver att melankoli på r6oo-talet var ett "luddigt tillstånd", även i medicinsk litteratur. Den kunde sitta i hjärnan, blodet eller magen och beroende på var den fanns var symptomen olika. Den viktigaste gränslinjen fanns mellan den geniala och den kroppsliga melankolin, vilket betydde att "melankoli hos en barberare [...] inte var det samma som melankoli bland de socialt och kulturellt bättre lottade". ${ }^{56}$

Melankoli fortsatte att plåga människor, och man upplevde sorg och ångest trots att tillståndet under upplysningstiden mera kopplades till nervsjukdomar. Renässansens diskurs om det melankoliska geniet ändrades med I70o-talets nervlära och även om man associerade melankoli med skapande och intelligenta män skrev också kvinnor om sjukdomen. Den engelska diktaren Anne Finch (I66I-I720) skrev om mjältsjuka ("spleen"), sjuka nerver, sorg och ångest i sina dikter. Senare skrev även Mary Wollstonecraft (I759-I797) och Charlotte Smith (I749-1806) om ämnet. Dessa författare både kämpade för kvinnans rätt till kreativt arbete och skrev om sina erfarenheter av depression i relation till denna kamp. Smith var en självmedveten diktare som i en sonett skrev att "den som känner det största svårmodet, porträttterar det bäst". ${ }^{57}$

Om vi vidgar horisonten från depressiva tillstånd till olika typer av ångest och livskriser så hittar vi kvinnor som skriver om sin inre kamp redan före upplysningstiden. En av dessa stammödrar för kvinnors

56. "melancholy in a barber [...] was not the same as melancholy is his social and cultural betters", Erin Sullivan, Beyond Melancholy: Sadness and Selfhood in Renaissance England, Oxford: Oxford University Press 2016, s. 93, https://doi.org/Io.Io93/ acprof:oso/9780I98739654.0or.ooor. Översättning till svenska: KT.

57. Clark Lawlor, From Melancholia to Prozac: A History of Depression, Oxford: Oxford University Press 20I2, s. 88-99. Orig. i Charlotte Smith, Elegiac Sonnets, ursprungligen utgivna 1784 , Sonnet I, "Ah! then, how dear the Muse's favors cost, / If those paint sorrow best-who feel it most". Översättning av citatet: KT, se The Poems of Charlotte Smith (ed. Stuart Curran), Women Writers in English 1350-1850, New York, Oxford: Oxford University Press 1993, s. I3. 
själsliga autobigrafier är engelska Margery Kempe (I373-I438)."The Book of Margery Kempe" (ca r440) är den första autobiografin på engelska, en andlig sådan, som beskriver "sinnets inre liv" ("the inner life of the mind"). ${ }^{58}$ Margery Kempe födde sitt första barn som mycket ung och var vansinnig ("out of her mind") i åtta månader. Under denna tid såg och hörde hon "djävulen med den glödande tungan" och också senare hade hon episoder då hon blev vansinnig och tänkte att vansinnet kom från djävulen. Dale Peterson skriver: "alla hennes ovanliga mentala erfarenheter är beskrivna i passiv form, för att beteckna hur spirituella krafter trängde in i själen." ${ }^{\circ 9}$ Själens fiende, $i$ form av vansinnet, kom enligt detta synsätt utifrån. ${ }^{60}$

Margery Kempes erfarenheter och symptom, hennes ångestfyllda och rasande beteende påminner om sådana smärtsamma episoder $\mathrm{i}$ livet som också senare patienter beskrivit, men samtidigt är hennes religiösa värld annorlunda. Att hon blev bättre tack vare den andliga kraft som utgör djävlens motsats, "Our Merciful Lord Jesus Christ" som uppenbarade sig för henne i form av en vänlig man i fin silkeskostym, skiljer henne också från senare berättare. ${ }^{11}$ Hon hade erfarenheter som vi kan identifiera som hallucinationer och syner, men enligt henne var de verkliga visioner som kunde komma från antingen Gud eller djävulen. Margery Kempes I40o-talsvärld var starkt religiös och andlig, men är ändå inte alldeles främmande för oss. Att insjukna i depression beskrivs ännu i dag som en resa till helvetet. Minna Lindberg använder denna metafor, som också generellt är vanlig $i$ västerländska berätterser om psykiska sjukdomar. ${ }^{62}$ När den finska Aino Manner

58. Margery Kempe, The Book of Margery Kempe, British Library, https://www.bl.uk/ collection-items/the-book-of-margery-kempe (hämtad 28/6 2019).

59. "All her unusual mental experiences are described in passive form, denoting the intrusion of spiritual forces onto the self", Dale Peterson, "I436: The Book of Margery Kempe", Dale Peterson (ed.), A Mad People's History of Madness, Pittsburgh: University of Pittsburgh Press I982, s. 6-8. Översättning till svenska KT.

6o. Se också Radden, Moody Minds Distempered, s. I7o.

6r. Margery Kempe, “The Book of Margery Kempe” in Dale Peterson (ed.), A Mad People's History of Madness, Pittsburgh: University of Pittsburgh Press 1982, s. 8-10.

62. Rachel Falconer, Hell in Contemporary Literature: Western Descent Narratives since 1945, Edinburgh: Edinburgh University Press 2005, s. Ir3; se också Kirsi Tuohela \& Ritva Hapuli, "Mielen ja maailman taistelutantereet. Hajoamisen ja kauhun kokemuksia naisten teksteissä”, Viola Parente-Čapková et al. (toim.), Nainen kulttuurissa, kulttuuri naisessa, Turku: Kulttuurihistoria 2015, s. I55-I80. Finns även 
på I930-talet skrev den första finskspråkiga självbiografin om psykisk sjukdom (Viesti yöstä. Mielisairaalakokemuksia, 1935) använde också hon många religiösa metaforer i sin berättelse. ${ }^{63}$

Också Ann Hawkins hävdar att ett mytiskt och metaforiskt språk fortfarande i dag är ett viktigt uttrycksmedel i sjukdomsberättelser. Enligt henne bygger metaforerna på två gamla paradigm, "kampen mellan en mänsklig hjälte och en monstruös fiende och det kosmiska kriget mellan två typer av gudomligheter" ${ }^{64}$ De här två paradigmen rör kampen mellan ljus och mörker, liv och död, det goda och det onda, liksom hälsa och sjukdom. Den kristna dualismen har rotat sig djupt i kulturen och enligt den har den kristna goda människan kämpat emot "mörkrets härskare i världen" ${ }^{65}$ Sjukdomar ses som fiender och inkräktare från mörkret, och därmed har den goda patienten ansetts ha en plikt att kämpa emot, menar Hawkins. I 2000-talets finska depressionsberättelser kan man fortfarande se den här tendensen tydligt. Även om alla huvudpersoner inte tror på möjligheten att tillfriskna helt, kämpar de hårt för att må bättre och väljer att vittna om just detta.

Det stod klart för Margery Kempe att det själsliga lidandet alltid kom utifrån; hon själv var ett passivt offer för krafter som var starkare än en människa. I sin passivitet är hon olik den 2000-talspatient som undersöker sin identitet som psykiskt sjuk och sin position som subjekt eller objekt i den sekulära, vetenskapliga världen. Den viktiga skillnaden är att den nutida patienten inte längre söker sin gud utan medicinsk hjälp - hon vill bli hörd och mött, men inte av gud utan av vårdsystemet och samhället. Genom att skriva vill hon prisa vetenskapliga framsteg som mediciner eller terapi, inte Herren - och, i många fall, också kräva sin rätt som patient och medborgare samt kritisera samhället för dess sätt att bemöta och vårda sårbara individer. ${ }^{66} \mathrm{Men}$

elektroniskt, http://urn.fi/URN:NBN:fi-fe2OI5I2I724780 (hämtad I3/8 20I9).

63. Tuohela \& Hapuli, "Mielen ja maailman taistelutantereet", s. I64-I66.

64. "the battle between human hero and monstrous foe and the cosmic warfare between two kinds of divinities", Hawkins, Reconstructing Illness, s. 6r. Översättning till svenska: KT.

65. Ibid., s. 63-65,"the rulers of the darkness of this world". Översättning till svenska: KT.

66. Katharina Bernhardsson, Litterära besvär. Skildringar av sjukdom i samtida prosa, Lund: ellerströms 2010, s. 32; Smith \& Watson, Reading Autobiography, s. I27-I28, I45-I47. 
fortfarande i dag har självbiografier också en existentiell dimension. De hänvisar till erfarenheter av ensamhet, utanförskap och ångest, samt känslan av tomhet. På det sättet liknar deras beskrivningar av inre kamp de vittnesmål vi har från äldre tidsperioder.

\section{DEPRESSION OCH SAMTIDEN}

I det medicinska sammanhanget började depression, den psykiska sjukdom som vi känner i dag, växa fram på I8oo-talet. Under I80o-talet ökade medicinens makt och psykiatrin började klassificera psykiska störningar på olika sätt. Somliga betonade psykologiska faktorer medan andra ansåg att psykiska sjukdomar egentligen var rent fysiska sjukdomar i hjärnan. Enligt Clark Lawlor var I8oo-talet det århundrade när det man kallat melankoli så småningom började diagnostiseras som "depression". ${ }^{67}$ Tack vare nya vetenskaper som psykologi och neurologi förstod man sig bättre på både hjärnan och människans beteende. Skiftet innebar att melankoli inte längre betraktades som en förståndssjukdom utan som en störning i känslolivet; den började transformeras och uppfattas som en "affektiv störning" ("mood disorder", "affective disorder"). ${ }^{68}$ Under det sena I80o-talet var tysken Emil Kraepelin (1856-1926) en centralgestalt inom psykiatrin. Med honom föddes det vetenskapliga, biomedicinska sättet att betrakta depression som är rådande ännu i dag. ${ }^{69}$

Den psykiatriska sjukdomskategori som vi i dag känner som " $\mathrm{F}_{32}$ Depression" har sin egen vetenskapliga biografi med olika samhälleliga tolkningar av den banbrytande betydelse som den nya kategoriseringen hade. Sociologer har påpekat att depressionen blev en folksjukdom i Finland på 1980- och 1990-talen när det amerikanska klassificeringssystemet och nya epidemiologiska uppfinningar introducerades hos oss. ${ }^{70}$ Utan att närmare diskutera detaljerna kring detta fenomen, kan

67. Lawlor, From Melancholia to Prozac, s.io2.

68. Ibid.

69. Ibid., s. I36.

70. Ilpo Helén, Pertti Hämäläinen \& Anna Metteri, ”Komplekseja ja katkoksia psykiatrian hajaantuminen suomalaiseen sosiaalivaltioon", Ilpo Helén (toim.), Reformin pirstaleet. Mielenterveyspolitiikka byvinvointivaltion jälkeen, Tampere: Vastapaino 20II, s. 29-38. 
man konstatera att mängden av självbiografiska berättelser om just depression också började öka från I980-talet. Trots att vissa finska sociologer tycker att depression i dag, på 2000-talet, inte har särskilt mycket att göra med diagnosen depression 6o år tidigare, finns det också sociologer och historiker som drar idéhistoriska linjer och vill peka på intressanta kontinuiteter.

Den svenska idéhistorikern Karin Johannisson skriver om depression i ett långt historiskt perspektiv och kallar den vår tids melankoli. ${ }^{71}$ Med hjälp av begreppet anomi, som lanserats av sociologen Émile Durkheim, försöker hon ge en generell bild av vad depression är, och mera specifikt vad sjukdomen är i vår tid. ${ }^{72} \mathrm{I}$ begreppet anomi kommer 'a' från 'icke' och 'nomos' från 'lag'; anomi syftar således på något laglöst och regellöst. För Johannisson är den nutida depressionen just detta, "förvirring och vilsenhet", livet i ett samhälle där normerna är osynliga, motstridiga och oklara. Den moderna depressionen är bunden till moderniteten och storstäderna och därtill är den ett tillstånd hos både individen och samhället. Med hänvising till Durkheim skriver Johannisson att nutida människor måste söka sin egen väg till framgång och synlighet trots att spelreglerna är oklara - i det här spelet lyckas några och andra inte. ${ }^{73}$ Hon menar att både de som lyckas och de som känner sig mislyckade är drabbade. Antingen blir man deprimerad och upplever isolering, besvikelse, maktlöshet, utanförskap och att man är värdelös, eller så är man ständigt missnöjd med det man uppnår och hungrar efter mer. Man hamnar i en "rastlös jakt på tillfredsställelse" och "blir omättlig, men också omåttlig”. "Den anomaliska melankolin har alltså ett dubbelt ansikte: apati och mani”, sammanfattar Johannisson. ${ }^{74}$

Karin Johannisson pekar på de långa linjerna och sociologer som diskuterar depression i ett samhälleligt perspektiv har dragit liknande

7I. Karin Johannisson, Melankoliska rum: om ångest, leda och sårbarbet iförfluten tid och nutid, Stockholm: Bonnier 2009.

72. Johannisson hänvisar till en svensk översättning av Émile Durkheims klassiker, Le suicide: étude de sociologie (I897). Om 'anomi' (anomy) och 'anomic suicide', se t.ex. Émile Durkheim, Suicide: A Study in Sociology, Translated by John A Spaulding and George Simpson, London \& New York: Routledge 2010, s. 20I-239, 246-253, https://doi.org/Io.4324/9780203994320.

73. Johannisson, Melankoliska rum, s. 243-25I.

74. Ibid., s. 246-247. 
slutsatser. Liksom Johannisson anser också Alain Ehrenberg att en av nackdelarna med den hyperindividuella kultur vi lever i är depression. Jaget blir målet för allt och individen själv blir ansvarig för sitt jagprojekt, genom vilket hon antingen får tillträde till världen, till alla kulturella, sociala och ekonomiska resurser - eller inte. I båda fallen kan hon bli trött. Ehrenberg hävdar att psykiska sjukdomar, och av dem främst depression, är bundna till individualiteten och är "den största personliga olyckan i vår tid". Han hänvisar till ı980-talet som en vändpunkt och skriver:

Det här årtiondet var innovativt på ett annat sätt. Det var inte bara en fråga om att vara sig själv, att ge sig ut och leta efter sin 'autenticitet': man var också tvungen att agera på egen hand, lita på sina egna inneboende resurser.

Han menar att vi har byggt upp en kultur i vilken vi sjöng "den personliga uppfyllelsens gospel". ${ }^{75}$ För psykiatrins del betyder detta att depressionen blivit en kronisk identitetspatologi och manifesterar sig som en oförmåga att agera.

Som fysisk och emotionell erfarenhet är depressionen tung och många vittnar om att skrivandet hjälper. Att skriva om sin sjukdom betyder att man ger form åt sin erfarenhet. Autobiografin kan ses som ett självuttryck, men som Sidonie Smith påpekar är den alltid också en performativ handling. ${ }^{76}$ Den autobiografiska teorin, som är kritisk mot "självuttrycksteorin", utgår från uppfattningen att jaget som skrivs fram och förefaller komma inifrån, från psykets djup, egentligen inte är något essentiellt och enhetligt utan blir till genom skrivandet och den perfomativa handlingen. Man kan även hävda att erfarenheterna och den personliga historien är fragmentariska och att

75. "the major personal unhappiness of our time"; "This decade was innovative in another way. It was not simply a matter of being oneself, of setting out blissfully in search of one's 'authenticity'; one also had to act on one's own, to rely on one's own internal resources"; "the gospel of personal fulfilment", Ehrenberg, The Weariness of the Self, s. 3. Översättning till svenska: KT.

76. Sidonie Smith, "Performativity, Autobiographical Practice, Resistance", Sidonie Smith \& Julia Watson (eds.), Women, Autobiography, Theory: A Reader (eds.), Madison: The University of Wisconsin Press I998, s. IO8-II5, särskilt s. Io8. 
vi är alienerade från dem. Jaget är inte något färdigt och självklart som vi kan ta fram, utan vi måste konstruera det genom berättandet. ${ }^{77}$ Så här starkt tolkar jag ändå inte skrivandets och ordens, kulturens och diskursens betydelse. Möjligen upplever depressiva individer ändå sociala och kontroversiella krav särskilt starkt och upplever också därför oftare ett inre kaos. Det verkar i alla fall vara så att skrivandet och berättandet hjälper individerna själva; genom att berätta kan de bättre förstå vilka de är. Också i terapin konstruerar man berättelser, historier och ett jag. Minna Lindberg beskriver sin terapi och hänvisar till sin terapeuts ord så här:

- Det är bra att du berättar så öppet om dig själv och dina känslor. Terapin handlar om att lära sig om sig själv, om sin omgivning och sina känslor och det gör du enbart genom att vara öppen. Och min målsättning är att lära känna vem Minna är och vad som finns i hennes liv. Vem är Minna? ${ }^{78}$

Lindberg uppskattar terapeuten som hjälper henne att lära sig vem Minna är. Det är vägen till att må bättre.

Om möjligheten att genom terapi förändras och helas vittnar också Sippus i sin berättelse. Vad som sist och slutligen räddar Sippus och Lindbergs liv är ändå inte terapeuten utan familjen och vännerna. Sippus väg mot tillfrisknande går via en graviditet och att hon föder ett barn, "vår guldklimp, vår prinsessa". ${ }^{79}$ Lindberg säger det också: "Mina vänner och familj är orsaken till att jag lever." ${ }^{00}$ Att någon lyssnar är viktigt men detta måste kompletteras med nära emotionella relationer, kärleksfulla upplevelser av godkännande. Man vill bli hörd, sedd och mött som sitt eget jag.

77. Ibid.

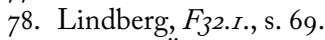

79. Sippus, "Önskan att dö", s. II8-II9.

8o. Lindberg, Diagnos F32.I., s. 71, 74. 
I den här artikeln har jag diskuterat hur finländska kvinnor på 2000-talet har skrivit om sin egen depression, och genom skrivandet format sin identitet som en människa med depression.

Beträffande frågan hur livet, jaget och sjukdomen hör ihop har filosofen Jennifer Radden hävdat att somliga psykiska sjukdomstillstånd är mer centrala för jaget och identiteten än andra - och enligt henne är depression ett sådant tillstånd. Även om man kan integrera symptom och sjukdom i sin identitet också då man har en annan sjukdom, så är sjukdomens betydelse för identiteten speciellt uppenbar i depressionberättelser. Depression innebär starka känslor och sinnesstämningar som inte alltid är lätta att skilja från våra jag. Sinnesstämningen är starkt knuten till erfarenhet och när sjukdomen är långvarig så blir dessa lätt en del av oss själva. ${ }^{81}$

I den här artikeln har jag diskuterat hur nära identiteten depressionen ligger, på vilket sätt den möjligen blir en del av ens självbild. Jag har frågat mig hur kvinnor som Lindberg, Vanhatalo och Sippus upplevde och beskrev sina svåra livsperioder och känslor, såsom sorg, långvarig nedslagenhet och modlöshet. Jag har analyserat hur de här kvinnorna konstruerade sin depressiva identitet, sin egen berättelse som en person med depression. Deras berättelser om sammanbrott och tillfrisknanden i det senmoderna samhällets kontext vittnar om att skrivandet om depression har ökat. Kanske drabbar depression allt fler på grund av den individualisering som Sarrimo, Johannisson och Ehrenberg diskuterar och allt flera människor skriver också om detta. Berättelserna vittnar också om vittnesmålets och "de sanna berättelsernas" betydelse i den nutida kulturen.

Alla de tre författarna i mitt primärmaterial har skrivit som vittnen, sårade berättare som upplevt ett lidande som nästan tycks tvinga dem att tala ut. Det sägs inte explicit men på 2000-talet tycks offentligheten, också smärtsamma texter om det svåra utgivna i bokform, tillhöra kvinnor lika självklart som den tillhör männen. Att det är kvinnor som skriver om depression - och lider av den mer än män - kan ha sin orsak i den ytterst individualiserade kultur som kräver

8I. Radden, Moody Minds Distempered. s. I69, I75-176. 
synlighet, autenticitet och framgångar. Detta krav kanske gör kvinnor, som också är mödrar och ofta tar hand om andra i högre grad än män, mer sårbara. ${ }^{82}$ Det är också möjligt att kvinnor finner det lättare att skriva om den typ av inre - men också social - kamp, som insjuknandet i depression innebär. Hur som helst, gemensamt för de tre berättelser jag studerat i artikeln är att de framför budskapet att psykiska sammanbrott kan drabba vem som helst. Den drabbade ska därför inte skämmas utan måste bli synlig i samhället. Alla de tre jagberättarna söker och hittar också en identitet som en människa som insjuknat i depression. Rösten som berättar hur plågsamt det känns blir framställd och hörd.

Vilken identitet som formas i texten varierar ändå. Vanhatalo och Lindberg vittnar mångsidigt om sina erfarenheter och sökandet efter en förändring och en ny identitet. De accepterar slutligen sin depression men ger inte upp totalt utan hittar en "mellanrumstillvaro", mellan sjukdom och att vara frisk. De bygger upp en ny identitet, en som mår bättre men som kanske aldrig kan bli helt fri från sin sjukdom: depressionen, den mörka sidan av jaget. Sippus skiljer sig från de andra; då hon föder ett barn börjar ett nytt skede i hennes liv och hon upplever att hon lärt sig något viktigt av sitt tillstånd. Hon har lärt sig att leva utan depression; hon har byggt upp en identitet som en människa som har blivit helt frisk, fri från den svåra, mörka sjukdomen, depressionen.

Till sist vill jag påpeka att hur man än ser på depression som fenomen, oberoende av hur "autentiska" eller socialt konstruerade man tänker sig att depressionsberättelser är, så är de ändå aktiva språkliga handligar som inbjuder oss till dialog. De påminner oss om hur viktigt det är att lyssna på dem som lider och har lidit av vilken sjukdom eller kris som helst. Jens Brockmeier och Lars-Christer Hydén skriver om lyssnandet och dess betydelse, att "sjukdom, olycka och oförmåga är gäster vi aldrig inbjuder till våra liv". ${ }^{83}$ Sjukdomar, trauman och psykologiska problem kommer ändå, och var och en av oss måste lära sig hur sköra våra liv egentligen är. Lidande, sjukdomar och trauman

82. Se också Lafrance, Women and Depression, s. Io9-II3.

83. "Illness, injuries and disabilities are guests we never invite to our lives", Hydén \& Brockmeier,"Introduction", s. 2. Översättning till svenska: KT. 
gör oss nåbara för andra, menar Hydén och Brockmeier, för i lidandets stund hoppas vi att någon lyssnar på oss, vår historia, våra röster, våra erfarenheter. ${ }^{84}$ Trots att vi uppträder på jagets populära och ibland kommersiella scen när vi väljer att publicera våra berättelser, är det värt att komma ihåg att den etiska principen för mänsklig nåbarhet också är ett av motiven för att berätta - och en påminnelse om att vi ska lyssna på den som berättar.

84. Ibid. 